\title{
VEGETATION FUNCTION AND DIVERSITY ON RECLAIMED SURFACE-MINED LANDS OF SOUTHEASTERN OHIO, USA ${ }^{1}$
}

\author{
Douglas J. Spieles², Emily Bennett, William Weems, and Rebecca Swab
}

\begin{abstract}
Surface coal mining has transformed certain regions of Appalachia. Reclamation laws have evolved over the past fifty years, creating spatiotemporal variability in reclaimed landscapes. While the vegetation composition of reclaimed lands is well understood, less is known about the associated development of ecological function. We used two attributes of the plant community-diversity and the capacity to absorb photosynthetically active radiation-as fundamental indicators of ecosystem composition and function. Using both satellite-derived light reflectance and field sampling, we characterized the successional trajectory of reclaimed lands, reference forest, and reference grasslands in southeastern Ohio, USA. We also assessed the importance of active management in ecosystem restoration. The reclaimed lands in this study represent four different eras of regulation, from pre-1972 to post-1981. We compared the Normalized Difference Vegetation Index (NDVI) within and among sites from 2000-2016, and the Shannon-Wiener diversity index among sites in 2016-2017. In this study, the oldest reclamation sites (45-50 years since reclamation) achieved the highest capacity for light absorption by 2016, suggesting that time since disturbance, reclamation technique, or a combination of the two are conducive to the restoration of ecological function. Younger reclaimed sites (25-35 years since reclamation) accrued function more rapidly than older sites - reaching NDVI equivalence with reference ecosystems 28-34 years after mining-suggesting that reclamation technique can accelerate recovery. Active management of reclaimed lands does not improve light absorption capacity, but it does increase plant diversity, which is linked to a variety of other ecological functions.
\end{abstract}

Additional Key Words: Appalachia, ecosystem restoration, remote sensing, NDVI

1 Paper submitted for consideration in JASMR and Published by ASMR; 1305 Weathervane Dr., Champaign, IL 61821.

2 Douglas J. Spieles is Professor of Environmental Studies at the McPhail Center for Environmental Studies, Denison University, Granville, OH 43023; Emily Bennett and William Weems are Denison University students; Rebecca Swab is Director of Restoration Ecology at The Wilds, Cumberland, OH 43732.

DOI: $\underline{\text { htp://dx.doi.org/10.21000/JASMR19020052 }}$ 


\section{Introduction}

Over the past two centuries, large expanses of the Appalachian landscape have been transformed by surface coal mining (Zipper et al., 2011). The general ecological effect of this activity is the conversion of late-successional (typically forested) ecosystems into physically- and chemically-stressed systems with a comparatively simple structure and composition (often grasslands). As conceptualized by Odum (1985), stress-derived changes to ecosystem structure and composition are typically accompanied by alterations in ecological function, such as inefficiency of nutrient cycling and reduced productivity. Succession may resume as stress is alleviated, though the resulting ecosystem structure, composition, and function may be novel (Brenner et al., 1984). The history of Appalachian surface mining and reclamation presents an opportunity to evaluate ecosystem response to stress and successional trajectory over large spatial and temporal scales.

Previous research on the ecological recovery of former surface-mined land suggests that a return to pre-mining ecological conditions is not easily achieved. For example, Holl (2002) compared vegetation on reclaimed and reference sites in southwest Virginia and determined that vegetation cover on mined sites approaches that of native communities over time, but that plant species composition differs substantially from native communities even after three decades of recovery (see also Holl and Cairns, 1994). Cavender et al. (2014) also reported that 30-year old reclaimed sites support a grassland with more nonnative species that significantly differs from unmined reference sites in structure and composition. These results reflect the goals of reclamation, which are intended to address immediate needs such as landscape contouring, rapid establishment of vegetation, rehabilitation of soil conditions, and prevention of erosion. Such techniques may be essential for ecological stabilization, but they are not necessarily intended to achieve long-term equivalence with native ecosystems (Bell and Ungar, 1981; Holl and Cairns, 1994; Holl, 2002).

Reclamation laws and regulations have evolved over time, in part to facilitate ecological recovery. Prior to the 1970 s, many surface mine sites were abandoned with minimal recontouring and limited topsoil replacement (Skousen et al., 1994; Plass, 2000; Cavender et al., 2014). These lands are typically characterized by a mixture of remnant vegetation, species planted or colonized on ungraded spoil, and highly erodible or contaminated microsites that are unsuitable for 
colonization long after the cessation of mining (Skousen et al., 1994; Cavender et al., 2014). With 1972 legislation in Ohio and the 1977 federal Surface Mining Control and Reclamation Act (SMCRA), new regulations required recontouring, regrading, topsoil replacement, and the rapid establishment of vegetation (Torbert and Burger, 2000). These mandates improve the topography, viability and stability of reclaimed sites, though they also tend to increase soil compaction and shift the revegetation process toward nonnative herbaceous species (Zipper et al., 2011; Cavender et al., 2014). In some cases, persistent nonnative vegetation and extreme soil compaction have decreased the likelihood of native woody recruitment (Torbert and Burger, 2000; Holl 2002; Zipper et al., 2011). Passively managed (i.e.. reclaimed and abandoned) sites can thus remain in a state of arrested succession, showing no trajectory toward the establishment of a forest (Cavender et al., 2014). Comparatively active management techniques—-such as soil amendment, microsite planting preparation, nonnative species removal, nurse species introduction, and establishment of tree-compatible ground cover-have shown some promise in the re-establishment of a forest community (Torbert and Burger, 2000; Carter and Ungar, 2002; Zipper et al., 2011). Clearly, the methods of reclamation and management are critical factors in the successional fate of surfacemined land.

While it is well established that former surface-mined lands support a different vegetation structure and composition than unmined reference ecosystems, less is known about the ecological function of reclaimed ecosystems. Various scholars have proposed schemes of defining vegetation function, based on community attributes such as contribution to ecological processes (Walker et al., 1999), response to environmental change (Lavorel et al., 1997), and trophic dynamics (PahlWostl, 1995). While all have merit, these concepts of function can be difficult to evaluate over large spatial and temporal scales. A more fundamental measure of function is the capacity of the plant community to absorb photosynthetically active radiation (PAR; Cabello et al., 2012). As a remotely accessible indicator of vegetation health and stress, absorption of PAR has the advantage of large-scale application (Kerr and Ostrovsky, 2003). Given the expanse of Appalachian surface mining, evaluation of time-series PAR in locations subjected to different reclamation and management techniques can provide insight on the functional efficacy and successional trajectory of reclaimed ecosystems.

In this study, we characterize post-mining vegetation development through different eras of reclamation in southeastern Ohio. Sixteen years of satellite-derived spectral reflectance data were 
used to evaluate longitudinal changes in vegetation health within and among areas of different reclamation treatment. Using both remote and field surveys, we compared vegetation health of passively managed reclamation sites with that of unmined reference sites as well as mined-andreclaimed sites that have been actively managed for ecological restoration. This approach addressed some fundamental questions of surface mine reclamation: 1. Have historic changes to surface mine reclamation techniques resulted in a more robust or rapid establishment of vegetation on reclaimed lands? 2. Do reclaimed lands that are passively managed attain functional equivalence with native ecosystems over time? 3. Does active management accelerate the successional recovery of functional vegetation on reclaimed land?

\section{$\underline{\text { Methods }}$}

\section{$\underline{\text { Site Description }}$}

Surface coal mine reclamation lands of Morgan and Muskingum Counties in southeastern Ohio were selected as study sites based on the timing of their permitted reclamation activity (Fig. 1): Site A (reclaimed prior to 1972); Site B (reclaimed 1972-1975); Site C (reclaimed 1976-1981); and Site D (reclaimed after 1981). These lands were selected to evaluate the changes brought about by reclamation legislation, notably the 1972 Ohio Strip Mine Law and the 1977 SMCRA. As passively managed reclamation lands, these study sites are dominated by cool-season grasses and nonnative herbaceous vegetation, variously interspersed with shrubs and trees. We chose two sets of reclamation lands (Fig. 1): Am-Dm are sites in greater Morgan and Muskingum Counties that we used as remote sampling locations; Aw-Dw are sites within the Wilds conservation area, used for both remote and field sampling. The reference sites (Fig. 1) included Blue Rock State Forest (unmined forest), the Wilds (mined and reclaimed grassland, actively managed for ecological restoration) and at Ridges Land Lab in Athens County (unmined grassland). The reference forest $(\mathrm{RF})$ provided a comparison with the pre-mining ecological condition of this region, while the reference grasslands $(\mathrm{RG})$ allow for comparison with mined and unmined lands dominated by grasses and forbs.

The 1850 hectare (ha) Blue Rock State Forest consists of unmined former agricultural land, obtained by the federal government in the 1930s and later turned over to the state of Ohio for reforestation. The forest canopy, like much of the secondary-growth forest in this part of the state, is primarily comprised of oak (Quercus spp.), hickory (Carya spp.), maple (Acer spp.), and beech 
(Fagus spp.) (Goebel and Hix, 1996). Ridges Land Lab is an 80-ha educational, research and conservation center under the direction of Ohio University (Meekins and McCarthy, 2001). It is an unmined area of secondary mixed hardwood forest and grassland, including 10 ha of tallgrass prairie.

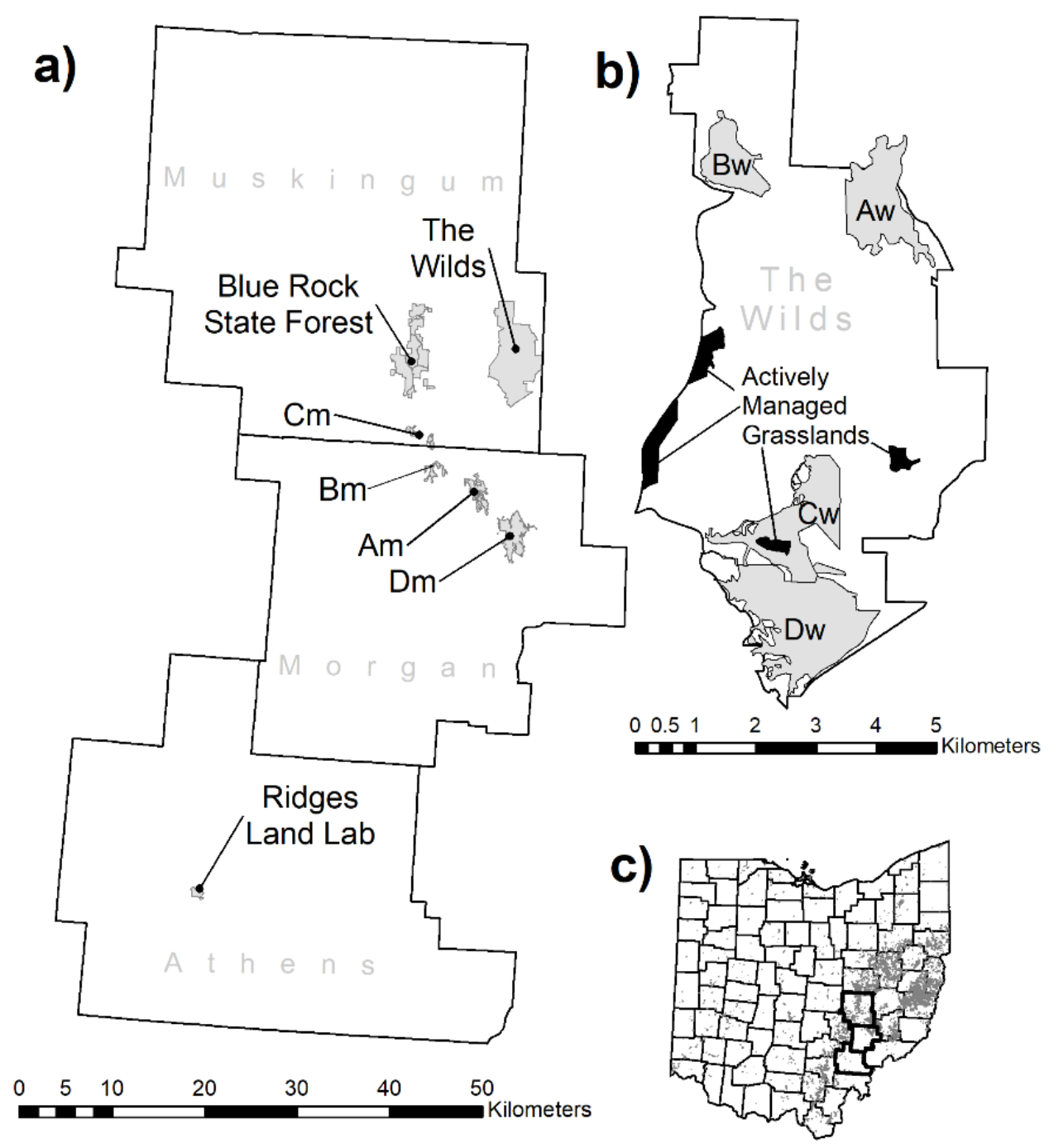

Figure 1. Location of a) study sites in Athens, Morgan and Muskingum Counties of eastern Ohio, USA. Letters indicate sites of different reclamation eras: Site Am (reclaimed prior to 1972); Site Bm (reclaimed 1972-1975); Site Cm (reclaimed 1976-1981); and Site Dm (reclaimed after 1981); b) reclamation sites of the same eras within the Wilds, indicated as Aw-Dw, and actively managed grassland reference sites; and c) the three-county study area within the context of Ohio, showing all surface mine reclamation lands as of 2017. Source: Ohio Department of Natural Resources, Divisions of Mineral Resources and Geological Survey. 
The Wilds, a 3700-ha center for conservation, education, and research, was the site of surface mining and reclamation in the 1940s and 1950s, and again from the 1960s through 2001 (Byrd et al., 2012). The Wilds features passively managed areas from all four eras of mining reclamation (Aw-Dw), as well as reclamation lands that are actively managed as restored prairies. Nearly 280 ha of prairies have been planted on the Wilds lands between 1999 and 2016. The prairies consist of warm season perennial grasses such as Panicum virgatum, Sorghastrum nutans, and Andropogon gerardii, mixed with a variety of forbs and maintained with periodic prescribed burns. For each of the reference ecosystems at the Wilds, Ridges Land Lab, and Blue Rock State Forest, along with reclamation Sites Am-Dm and Aw-Dw, a 30m x 30m grid overlay was created, and a random number generator was used to select field and remote sampling locations on terrestrial habitat (Table 1).

Table 1. Attributes, coordinates and sampling information for Study Sites.

\begin{tabular}{|c|c|c|c|c|c|c|}
\hline \multirow{2}{*}{$\begin{array}{l}\text { Study } \\
\text { Site }\end{array}$} & \multirow[b]{2}{*}{ Status } & \multirow{2}{*}{$\begin{array}{l}\text { Reclamation } \\
\text { Law Era }\end{array}$} & \multirow[b]{2}{*}{ Coordinates } & \multirow{2}{*}{$\begin{array}{l}\text { Sample Site } \\
\text { Area (ha) }\end{array}$} & \multicolumn{2}{|c|}{ Sampling Locations (number; year) } \\
\hline & & & & & Remote & Field \\
\hline Am & $\begin{array}{l}\text { mined and reclaimed } \\
\text { passively managed }\end{array}$ & $1965-1972$ & $\begin{array}{l}39^{\circ} 42^{\prime} 45^{\prime \prime} \mathrm{N} \\
81^{\circ} 46^{\prime} 00^{\prime \prime} \mathrm{W}\end{array}$ & 440 & $20 ; 2000-2016$ & - \\
\hline $\mathrm{Bm}$ & $\begin{array}{l}\text { mined and reclaimed } \\
\text { passively managed }\end{array}$ & $1972-1975$ & $\begin{array}{l}39^{\circ} 44^{\prime} 00^{\prime \prime} \mathrm{N} \\
81^{\circ} 49^{\prime} 50^{\prime \prime} \mathrm{W}\end{array}$ & 160 & $20 ; 2000-2016$ & - \\
\hline $\mathrm{Cm}$ & $\begin{array}{l}\text { mined and reclaimed } \\
\text { passively managed }\end{array}$ & 1976-1981 & $\begin{array}{l}39^{\circ} 46^{\prime} 21^{\prime \prime} \mathrm{N} \\
81^{\circ} 51^{\prime} 20^{\prime \prime} \mathrm{W}\end{array}$ & 130 & $20 ; 2000-2016$ & - \\
\hline Dm & $\begin{array}{l}\text { mined and reclaimed } \\
\text { passively managed }\end{array}$ & 1981- & $\begin{array}{l}39^{\circ} 40^{\prime} 39^{\prime \prime} \mathrm{N} \\
81^{\circ} 43^{\prime} 30^{\prime \prime} \mathrm{W}\end{array}$ & 830 & $20 ; 2000-2016$ & - \\
\hline $\begin{array}{l}\text { RF Blue Rock } \\
\text { St. Forest }\end{array}$ & $\begin{array}{l}\text { unmined reference } \\
\text { forest }\end{array}$ & - & $\begin{array}{l}39^{\circ} 50^{\prime} 30^{\prime \prime} \mathrm{N} \\
81^{\circ} 51^{\prime} 30^{\prime \prime} \mathrm{W}\end{array}$ & 1800 & $20 ; 2000-2016$ & - \\
\hline $\begin{array}{l}\text { RG Ridges } \\
\text { Land Lab }\end{array}$ & $\begin{array}{l}\text { unmined reference } \\
\text { grassland }\end{array}$ & - & $\begin{array}{l}39^{\circ} 19^{\prime} 20^{\prime \prime} \mathrm{N} \\
82^{\circ} 07^{\prime} 30^{\prime \prime} \mathrm{W}\end{array}$ & 10 & - & $20 ; 2017$ \\
\hline $\begin{array}{l}\text { The Wilds } \\
\qquad \begin{array}{r}\text { Aw } \\
\text { Bw } \\
\text { Cw } \\
\text { Dw }\end{array}\end{array}$ & $\begin{array}{l}\text { mined and reclaimed } \\
\text { passively managed } \\
\text { grasslands }\end{array}$ & $\begin{array}{l}1965-1972 \\
1972-1975 \\
1976-1981 \\
1981-\end{array}$ & $\begin{array}{l}39^{\circ} 49^{\prime} 45^{\prime \prime} \mathrm{N} \\
81^{\circ} 44^{\prime} 00^{\prime \prime} \mathrm{W}\end{array}$ & 1600 & $\begin{array}{l}- \\
- \\
- \\
-\end{array}$ & $\begin{array}{l}20 ; 2017 \\
20 ; 2017 \\
20 ; 2017 \\
20 ; 2017\end{array}$ \\
\hline AMG & $\begin{array}{l}\text { mined and reclaimed } \\
\text { actively managed } \\
\text { grasslands }\end{array}$ & 1975-1981 & $\begin{array}{l}39^{\circ} 49^{\prime} 45^{\prime \prime} \mathrm{N} \\
81^{\circ} 44^{\prime} 00^{\prime \prime} \mathrm{W}\end{array}$ & 90 & $4 ; 2000-2016$ & $40 ; 2016$ \\
\hline
\end{tabular}

\section{Data Acquisition}

To remotely quantify vegetation status at sampling locations (Table 1), PAR reflectance data were collected from the Moderate Resolution Imaging Spectroradiometer (MODIS) satellite 
sensing system. These data are available through the VegScape database courtesy of the National Agriculture Statistics Service, United States Department of Agriculture (Boryan et al., 2011; Mueller, 2013). These data are expressed as the Normalized Difference Vegetation Index (NDVI; Tucker, 1979), which represents the spectral reflectance of red light (620-670 nm) relative to nearinfrared $(841-876 \mathrm{~nm}): \mathrm{NDVI}=(\mathrm{NIR}-\mathrm{R}) /(\mathrm{NIR}+\mathrm{R})$. NDVI ranges from -1 to 1 , with higher values indicating a greater density of green biomass (Karan et al., 2016). NDVI has long been used to assess land cover change and vegetation health associated with surface mining operations (e.g. Peñuelas and Filella, 1998; Latifovic et al., 2005; Townsend et al., 2009; Erener, 2011). MODISderived NDVI has a relatively low spatial resolution of $250 \mathrm{~m}$, but high temporal resolution of 1-2 d. Bi-weekly average NDVI pixel values were recorded for each sampling location from the beginning of April (week 14) through the end of September (week 36) for each year from 20002016. The total number of NDVI pixels sampled was 16,320 for reclaimed sites Am-Dm and 5,100 for reference sites at Blue Rock State Forest and the Wilds. These data sets facilitate the comparison of growing season NDVI within and among sites of four different reclamation eras, reference forest, and reference grasslands both actively and passively managed.

Vegetation diversity was determined at field sampling locations in the Wilds and Ridges Land Lab. Field sampling in the Wilds was restricted to four passively managed reclamation areas AwDw and four actively managed grasslands (AMG), encompassing a total area of approximately 1690 ha (Fig. 1). Ridges Land Lab field sampling was restricted to the tallgrass prairie reference grassland (RG), an area of approximately 10 ha. In August 2016 (Wilds AMG) and July 2017 (Wilds sites Aw-Dw and Ridges Land Lab RG) 100m transects were established in each location to quantify the plant community. At $10 \mathrm{~m}$ intervals, plants were identified to the lowest possible taxon and cataloged according to number of individuals per $\mathrm{m}^{2}$. In total, 80 quadrats were sampled in passively managed reclamation areas $\mathrm{Aw}-\mathrm{Dw}$, and 60 quadrats were sampled in reference sites at Ridges Land Lab and the Wilds. Species diversity was calculated using the Shannon-Wiener index (Shannon et al., 1951). This data set facilitates the comparison of plant community diversity among sites of different reclamation techniques and actively managed reference grasslands.

\section{$\underline{\text { Statistical Analyses }}$}

The biweekly composite NDVI values for weeks 14-36 were converted to quadratic curves. Curve parameters of reclamation areas Am-Dm were compared with the 95\% confidence interval of these values for the reference forest in 2016. To evaluate longitudinal NDVI trends, NDVI 
values at peak seasonal biomass (week 30; 7/25-8/7) were analyzed for representative years over the span of the study. These data and the model parameters of sites Am-Dm were compared with those from the reference forest using a linear regression analysis. The annual mean NDVI values among sites Am-Dm, the reference forest, and actively managed grasslands of the Wilds were compared with one-way ANOVA and Tukey's pairwise comparison of means. The field-derived vegetation diversity was assessed using a one-way ANOVA, comparing mean diversity with Tukey's pairwise analysis among reclaimed and passively managed sites Aw-Dw at the Wilds, reclaimed AMG sites at the Wilds, and unmined RG at Ridges Land Lab. In all analyses, significance was determined at $\alpha<0.05$ with JMP Pro 14.1.

\section{$\underline{\text { Results and Discussion }}$}

The quadratic curve parameters for seasonal NDVI of surface mined lands reclaimed prior to 1972 (Site Am) did not significantly differ from the curve parameters of the unmined reference forest in 2016 (Fig. 2a, Table 2a). This indicates that, in terms of growing season PAR absorption, Site Am vegetation appears to have achieved seasonal equivalence with the reference forest by 2000 and maintained equivalence through 2016. Curve parameters for Sites Bm-Dm are more erratic, being within the $95 \%$ confidence interval of the reference forest in 2008 but not in 2000 or 2016 (Fig 2b-d, Table 2a). When compared by growing season the mean NDVI (Fig. 4a), Site Am was statistically similar to the reference forest in both 2008 and 2016; Sites Bm and Cm were both similar to the reference site by 2016; however. Site Dm failed to achieve any statistical similarity

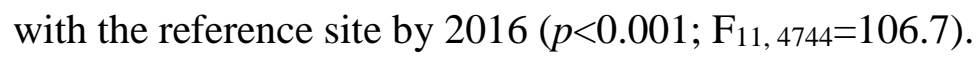

These results indicate that older reclamation sites have a higher capacity for PAR absorption. There could be several reasons for this. The most obvious reason is that the older reclamation sites had more time to recover from the impact of surface mining and are thus further along the productivity-stress gradient of succession (Prach and Hobbs, 2008). It may also be that mining and reclamation techniques prior to 1972 were less stressful than later techniques, for example in terms of vegetation recruitment. Pre-1972 reclamation typically involved planting hardwood seedlings in ungraded spoil, which did successfully establish forested areas in some locations. While the data in this study do not allow for causal discernment, it is notable that site age is positively associated with greater photosynthetic function throughout the growing season. This is consistent with observations of Brenner et al. (1984), who reported a positive relationship of site 
age with both plant biomass and chlorophyll- $a$ in reclaimed surface coal mined lands of western Pennsylvania. These authors attribute the increasing photosynthetic capacity to the establishment of volunteer species, both native and nonnative, on reclaimed lands (Brenner et al., 1984).
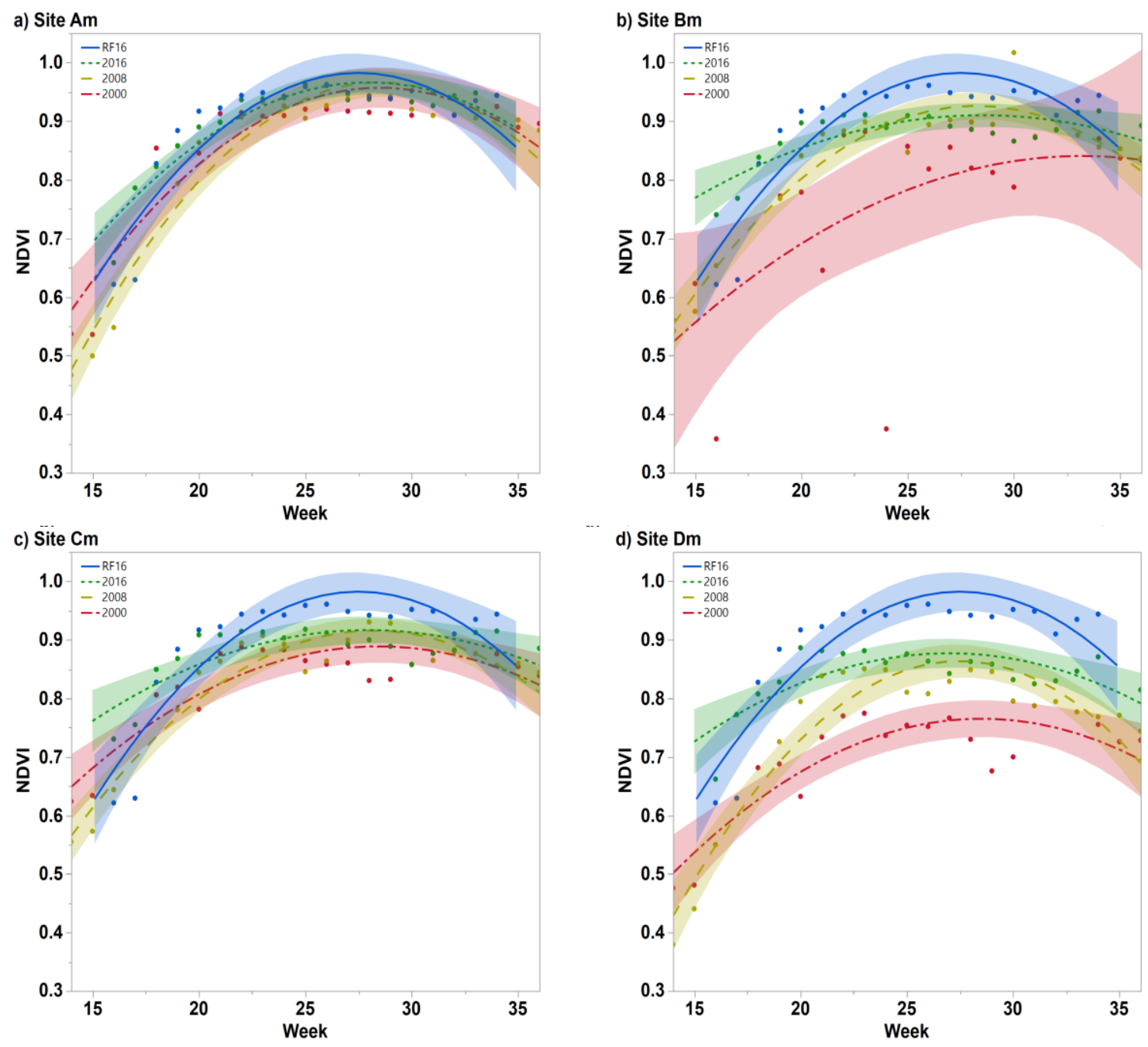

Figure 2. Seasonal curves of biweekly mean NDVI as compared with Reference Forest (RF) in 2016. Bands indicate 95\% confidence interval. Site letters indicate different reclamation era: a) Site Am (reclaimed prior to 1972); b) Site Bm (reclaimed 19721975); c) Site Cm (reclaimed 1976-1981); and d) Site Dm (reclaimed after 1981). 
Table 2. Curve parameters for a) seasonal NDVI quadratic fit, weeks 14-36 and b) linear fit for week 30 NDVI, 2000-2015 as compared with 95\% confidence interval for reference forest curve parameters. Asterisk indicates significant difference from reference parameter; NS indicates no significant difference.

\begin{tabular}{|c|c|c|c|c|}
\hline & $\mathrm{R}^{2}$ & Slope & Intercept & Quadratic \\
\hline \multicolumn{5}{|c|}{ a) Quadratic Fit for NDVI, weeks 14-36 } \\
\hline $\begin{array}{c}\text { Reference Forest } \\
2016\end{array}$ & 0.80 & $\begin{array}{l}95 \% \mathrm{CI} \\
(0.086,0.17)\end{array}$ & $(-1.25,-0.27)$ & $(-0.003,-0.0015)$ \\
\hline \multicolumn{5}{|l|}{ Site Am } \\
\hline $\begin{array}{l}2000 \\
2008 \\
2016\end{array}$ & $\begin{array}{l}0.84 \\
0.94 \\
0.86\end{array}$ & $\begin{array}{l}0.10^{\mathrm{NS}} \\
0.13^{\mathrm{NS}} \\
0.09^{\mathrm{NS}}\end{array}$ & $\begin{array}{l}-0.51^{\mathrm{NS}} \\
-0.93^{\mathrm{NS}} \\
-0.30^{\mathrm{NS}}\end{array}$ & $\begin{array}{l}-0.002^{\mathrm{NS}} \\
-0.002^{\mathrm{NS}} \\
-0.002^{\mathrm{NS}}\end{array}$ \\
\hline \multicolumn{5}{|l|}{ Site Bm } \\
\hline $\begin{array}{l}2000 \\
2008 \\
2016\end{array}$ & $\begin{array}{l}0.38 \\
0.91 \\
0.61\end{array}$ & $\begin{array}{l}0.06^{*} \\
0.10^{\mathrm{NS}} \\
0.04^{*}\end{array}$ & $\begin{array}{l}-0.10^{*} \\
-0.54^{\mathrm{NS}} \\
0.28^{*}\end{array}$ & $\begin{array}{l}-0.001^{*} \\
-0.002^{\mathrm{NS}} \\
-0.001^{*}\end{array}$ \\
\hline \multicolumn{5}{|l|}{ Site $\mathrm{Cm}$} \\
\hline $\begin{array}{l}2000 \\
2008 \\
2016\end{array}$ & $\begin{array}{l}0.79 \\
0.91 \\
0.59\end{array}$ & $\begin{array}{l}0.07^{*} \\
0.10^{\mathrm{NS}} \\
0.05^{*}\end{array}$ & $\begin{array}{l}-0.04^{*} \\
-0.47^{\mathrm{NS}} \\
0.19^{*}\end{array}$ & $\begin{array}{l}-0.001^{*} \\
-0.002^{\mathrm{NS}} \\
-0.001^{*}\end{array}$ \\
\hline \multicolumn{5}{|l|}{ Site Dm } \\
\hline $\begin{array}{l}2000 \\
2008 \\
2016\end{array}$ & $\begin{array}{l}0.76 \\
0.90 \\
0.55\end{array}$ & $\begin{array}{l}0.07^{*} \\
0.13^{\mathrm{NS}} \\
0.06^{*}\end{array}$ & $\begin{array}{l}-0.25^{*} \\
-0.95^{\text {NS }} \\
0.11^{*}\end{array}$ & $\begin{array}{l}-0.001^{*} \\
-0.002^{\mathrm{NS}} \\
-0.001^{*}\end{array}$ \\
\hline \multicolumn{5}{|c|}{ b) Linear fit for NDVI week 30, 2000-2015 } \\
\hline $\begin{array}{c}\text { Reference Forest } \\
2016\end{array}$ & $\begin{array}{l}95 \% \\
0.66\end{array}$ & $(0,0.004)$ & $(-6.95,0.91)$ & - \\
\hline $\begin{array}{l}\text { Site Am } \\
\text { Site } \mathrm{Bm} \\
\text { Site } \mathrm{Cm} \\
\text { Site } \mathrm{Dm}\end{array}$ & $\begin{array}{l}0.72 \\
0.96 \\
0.93 \\
0.95\end{array}$ & $\begin{array}{l}0.003^{\mathrm{NS}} \\
0.008^{*} \\
0.007^{*} \\
0.02^{*}\end{array}$ & $\begin{array}{l}-4.73^{\mathrm{NS}} \\
-15.02^{*} \\
-12.89^{*} \\
-29.58^{*}\end{array}$ & - \\
\hline
\end{tabular}

Time-series analysis of NDVI at peak growing season (Fig. 3) allows for an analysis of successional trajectory. The trajectory of Site Am during this study period was statistically indistinguishable from that of the reference forest, as the Bm-Dm sites differed significantly from the reference forest (Table 2b). Based on these data, grassland Sites Bm-Dm all achieved peak growing season NDVI equivalence with the reference forest by 2015 . This implies a recovery time of 40-43 years for Site Bm, 34-39 years for Site Cm, and 28-34 years for Site Dm. The significantly greater slope of NDVI increase on younger reclaimed lands may indicate an accelerated establishment of functional vegetation, perhaps due to historical improvements in reclamation technique. 
Other researchers have also used remote sensing to evaluate vegetation succession of former surface mined lands. Jing et al. (2015) used time-series NDVI analyses to characterize successional trajectory of reclaimed surface coal-mined lands of Virginia. They observed that the percentage of reclaimed lands with full vegetative cover correlated positively with time since reclamation, though the average time to NDVI equivalence with unmined reference conditions was less than that of our study, on the order of 12 years. Likewise, Sen et al. (2012) analyzed reclamation trajectory on mined lands of the same region and reported that some sites had not achieved NDVI equivalence with reference systems after 15 years. According to Yang et al. (2018), the reclaimed lands in our study follow a successional trajectory typical of post-disturbance photosynthetic recovery. Yang et al. (2018) note, however, that the rate of recovery may vary with specific site conditions.

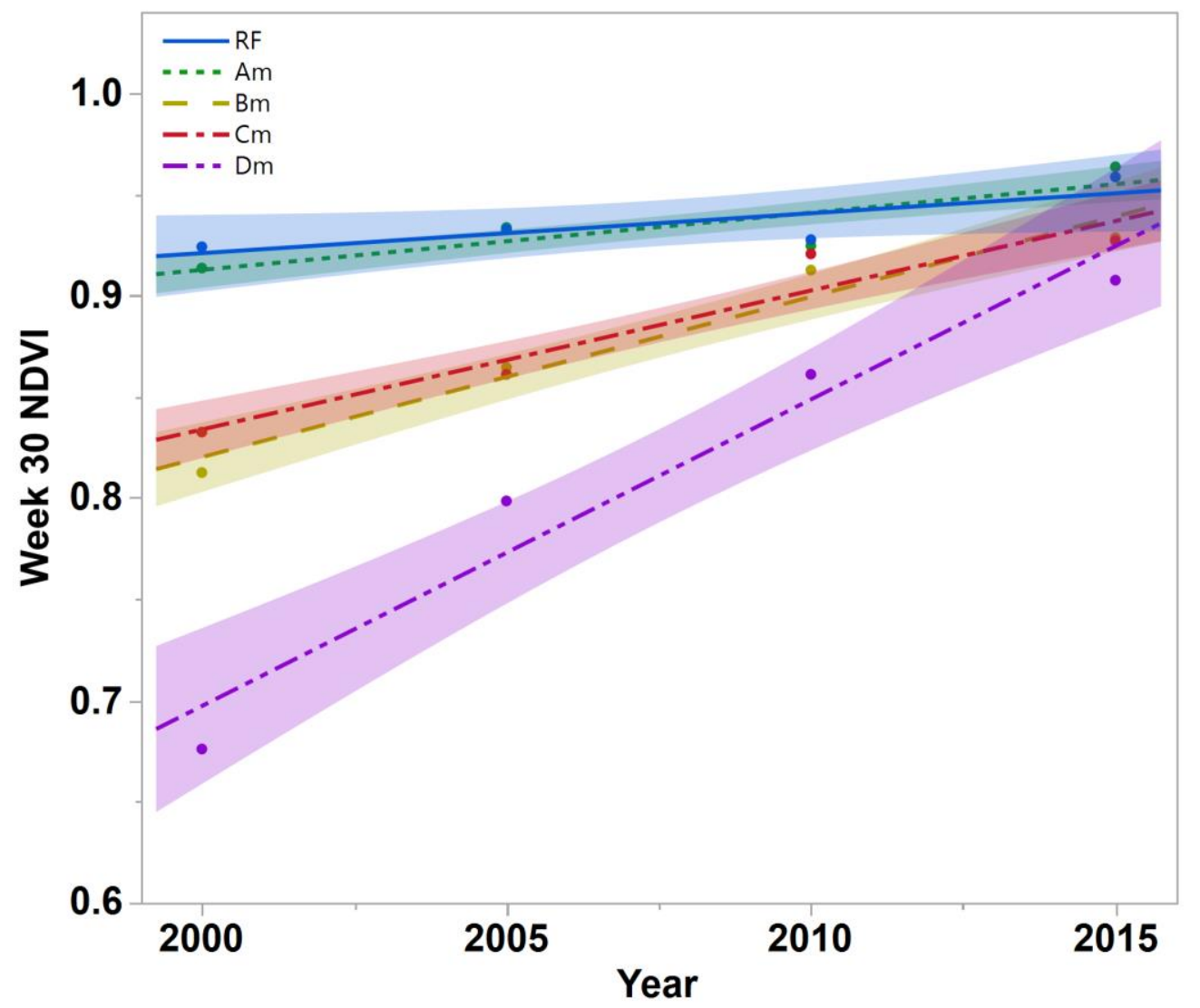

Figure 3. Linear fit and 95\% confidence interval of peak growing season (week 30) NDVI at sampling sites Am-Dm and Reference Forest (RF), 2000-2015. Letters indicate sites of different reclamation era: Site Am (reclaimed prior to 1972); Site Bm (reclaimed 1972-1975); Site Cm (reclaimed 1976-1981); and Site Dm (reclaimed after 1981) in Muskingum and Morgan Counties, Ohio. 
Of course, plant community PAR absorption is a basic measure of ecosystem function, and recovery of pre-mining NDVI is not the same as complete functional recovery (Yang et al., 2018). The wildlife value, functional niches, facilitation or inhibitory effects, and resilience of an established plant community may or may not follow a similar successional trajectory as NDVI. Likewise, plant community structure and composition may differ between reclaimed and unmined lands, even if NDVI values converge. In our study, the diversity of reclaimed lands Aw, $\mathrm{Cw}$ and $\mathrm{Dw}$ at the Wilds were statistically indistinguishable from the unmined reference grassland at Ridges Land Lab, while the diversity of Site $\mathrm{Bw}$ was significantly lower than the reference grassland (Fig. $4 \mathrm{~b} ; p<0.001, \mathrm{~F}_{5,148}=10.7$ ). Actively managed grasslands at the Wilds support a significantly greater plant diversity over surrounding reclaimed lands (Fig. 4b; $p<0.001$, $\mathrm{F}_{5,148}=10.7$ ), even though the actively managed grasslands achieved a lower average NDVI

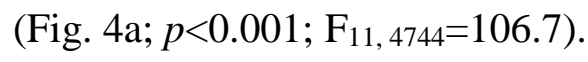

\section{$\underline{\text { Conclusions }}$}

This study demonstrates that former surface mine lands reclaimed approximately 50 years ago are better able to absorb PAR than younger reclaimed lands. In fact, the oldest reclaimed lands in this study absorb PAR at levels that are statistically indistinguishable from unmined reference forest. Younger reclaimed lands, even as they underperform the oldest lands in terms of NDVI, are gaining light-absorbing capacity more rapidly than their older counterparts. Thus, to the question of differential recovery of lands reclaimed in different eras we have a mixed response. These data also show that passively managed reclamation areas can achieve functional equivalence (in terms of NDVI) with unmined lands within a timeline of 30 to 45 years, regardless of reclamation era. Finally, we conclude that while active management of reclaimed lands does not appear to accelerate the ability of the ecosystem to absorb light, it can accelerate the development of plant community diversity - which may be associated with a host of ecosystem functions (Diaz and Cabido, 2001). In sum, the best conditions for the establishment of both productivity and diversity on former surface mined land are careful reclamation, active management, and time. 
a)

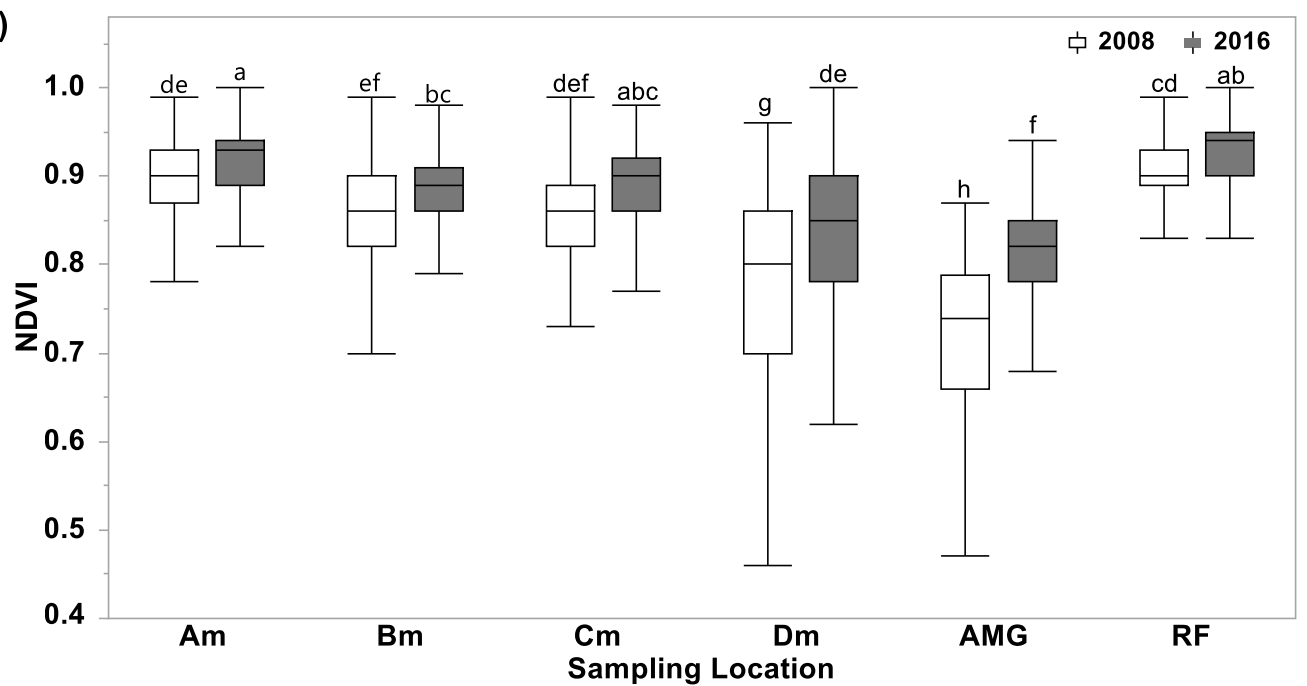

b)

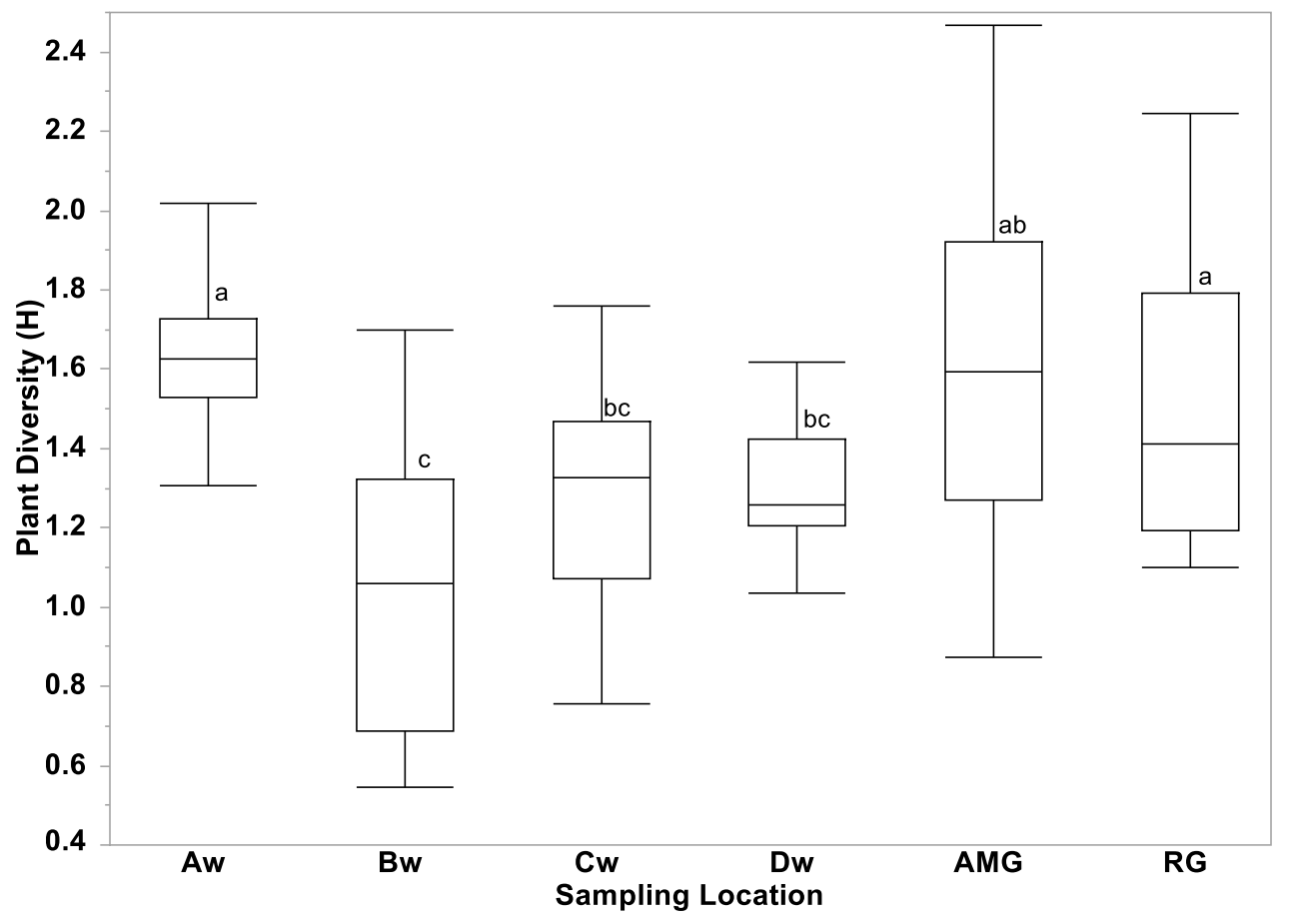

Figure 4. a) Median, range and quartile seasonal NDVI for Sites Am-Dm, Reference Forest (RF), and Actively Managed Grassland (AMG) in 2008 and 2016; and b) Median, range and quartile Shannon diversity index for Sites Aw-Dw, Reference Grassland (RG), and Actively Managed Grassland (AMG) based on field surveys in 2016 and 2017. Lower case letters indicate significant differences within each graph. 


\section{Acknowledgments}

This research was supported by funding from the Anderson endowment of Denison University. The cooperation and assistance of the Wilds, Ohio University, Ohio State Archives, and the Ohio Department of Natural Resources Division of Mineral Resources Management are gratefully acknowledged.

\section{$\underline{\text { Literature Cited }}$}

Bell, T.J. and I.A. Ungar. 1981. Factors affecting the establishment of natural vegetation on a coal strip mine spoil bank in southeastern Ohio. American Midland Naturalist 105:19-31. https://doi.org/10.2307/2425006

Boryan, C., Z. Yang, R. Mueller, and M. Craig. 2011. Monitoring US agriculture: the US department of agriculture, national agricultural statistics service, cropland data layer program. Geocarto International 26(5):341-358.

\section{https://doi.org/10.1080/10106049.2011.562309}

Brenner, F.J., M. Werner, and J. Pike. 1984. Ecosystem development and natural succession in surface coal mine reclamation. Minerals and the Environment 6(1):10-22. https://doi.org/10.1007/BF02072661

Byrd, S.M., N.D. Cavender, C.M. Peugh, and J.M. Bauman. 2012. Sustainable landscapes evaluating strategies for controlling autumn olive (Elaeagnus umbellata) on reclaimed surface mineland at the Wilds conservation center in southeastern Ohio. Journal of the American Society of Mining and Reclamation 193(1):1-9. https://doi.org/10.21000/JASMR12010001

Cabello, J., N. Fernández, D. Alcaraz-Segura, C. Oyonarte, G. Pineiro, A. Altesor, M. Delibes and J.M. Paruelo. 2012. The ecosystem functioning dimension in conservation: insights from remote sensing. Biodiversity and Conservation 21(13):3287-3305. https://doi.org/10.1007/s10531-012-0370-7

Carter, C.T. and I.A. Ungar. 2002. Aboveground vegetation, seed bank and soil analysis of a 31year-old forest restoration on coal mine spoil in southeastern Ohio. American Midland Naturalist 147:44-59. https://doi.org/10.1674/0003-0031(2002)147[0044:AVSBAS]2.0.CO;2 
Cavender, N., S. Byrd, C.L. Bechtoldt, and J.M. Bauman. 2014. Vegetation communities of a coal reclamation site in southeastern Ohio. Northeastern Naturalist 21(1):31-46. https://doi.org/10.1656/045.021.0104

Diaz, S. and M. Cabido. 2001. Vive la difference: plant functional diversity matters to ecosystem processes. Trends in Ecology \& Evolution 16(11):646-655. https://doi.org/10.1016/S0169$\underline{5347(01) 02283-2}$

Erener, A. 2011. Remote sensing of vegetation health for reclaimed areas of Seyitömer open cast coal mine. International Journal of Coal Geology 86(1):20-26. https://doi.org/10.1016/i.coal.2010.12.009

Goebel, P.C. and D.M. Hix. 1996. Development of mixed-oak forests in southeastern Ohio: A comparison of second-growth and old-growth forests. Forest Ecology and Management 84 (13):1-21. https://doi.org/10.1016/0378-1127(96)03772-3

Holl, K.D. 2002. Long-term vegetation recovery on reclaimed coal surface mines in the eastern USA. Journal of Applied Ecology 39(6):960-970. https://doi.org/10.1046/j.13652664.2002.00767.x

Holl, K.D. and J. Cairns. 1994. Vegetational community development on reclaimed coal surface mines in Virginia. Bulletin of the Torrey Botanical Club 121(4):327-337. https://doi.org/10.2307/2997006

Jing, L., C. Zipper, L. Song, P. Donovan, R. Wynne, A. Oliphant, and X. Qing. 2015. Character analysis of mining disturbance and reclamation trajectory in surface coal-mine area by timeseries NDVI. Transactions of the Chinese Society of Agricultural Engineering 31(16):251257.

Karan, S.K., S.R. Samadder, and S.K. Maiti. 2016. Assessment of the capability of remote sensing and GIS techniques for monitoring reclamation success in coal mine degraded lands. Journal of Environmental Management 182:272-283. https://doi.org/10.1016/j.jenvman.2016.07.070

Kerr, J.T. and M. Ostrovsky. 2003. From space to species: ecological applications for remote sensing. Trends in Ecology \& Evolution 18 (6):299-305. https://doi.org/10.1016/S0169$\underline{5347(03) 00071-5}$ 
Latifovic, R., K. Fytas, J. Chen, and J. Paraszczak. 2005. Assessing land cover change resulting from large surface mining development. International Journal of Applied Earth Observation and Geoinformation 7(1):29-48. https://doi.org/10.1016/.j.jag.2004.11.003

Lavorel, S., S. McIntyre, J. Landsberg, and T.D. Forbes. 1997. Plant functional classifications: from general groups to specific groups based on response to disturbance. Trends in Ecology \& Evolution 12:474-8. https://doi.org/10.1016/S0169-5347(97)01219-6

Meekins J.F. and B.C. McCarthy. 2001. Effect of environmental variation on the invasive success of a nonindigenous forest herb. Ecological Applications 11(5):1336-1348. https://doi.org/10.1890/1051-0761(2001)011[1336:EOEVOT]2.0.CO;2

Mueller, R. 2013. VegScape: a NASS web Service-based US crop condition monitoring system. United States Department of Agriculture (No. 147080).

Odum, E.P. 1985. Trends expected in stressed ecosystems. Bioscience 35(7):419-422. https://doi.org/10.2307/1310021

Peñuelas J. and I. Filella. 1998. Visible and near-infrared reflectance techniques for diagnosing plant physiological status. Trends in Plant Science 3(4):151-156. https://doi.org/10.1016/S1360-1385(98)01213-8

Pahl-Wostl, C. 1995. The dynamic nature of ecosystems: chaos and order entwined. John Wiley, New York.

Plass, W.T. 2000. History of surface mining reclamation and associated legislation. p. 1-20 In: Barnhisel, R., R. Darmody and W.L. Daniels, (Co-Eds.). 2000. Reclamation of drastically disturbed lands. American Society of Agronomy, Crop Science Society of America, and Soil Science Society of America, Madison, WI.

Prach, K. and R.J. Hobbs. 2008. Spontaneous succession versus technical reclamation in the restoration of disturbed sites. Restoration Ecology 16(3):363-366. https://doi.org/10.1111/j.1526-100X.2008.00412.x

Sen, S., C.E. Zipper, R.H. Wynne, and P.F. Donovan. 2012. Identifying revegetated mines as disturbance/recovery trajectories using an interannual Landsat chronosequence. Photogrammetric Engineering \& Remote Sensing 78(3):223-235. https://doi.org/10.14358/PERS.78.3.223 
Shannon, C.E., W. Weaver, and A.W. Burks. 1951. The mathematical theory of communication. University of Illinois Press, Urbana.

Skousen, J.G., C.D. Johnson, and K. Garbutt. 1994. Natural revegetation of 15 abandoned mine land sites in West Virginia. Journal of Environmental Quality 23(6):1224-1230. https://doi.org/10.2134/jeq1994.00472425002300060015x

Torbert, J.L. and J.A. Burger. 2000. Forest land reclamation. P. 371-398 In: Barnhisel, R., R. Darmody and W.L. Daniels, (Co-Eds.). 2000. Reclamation of drastically disturbed lands. American Society of Agronomy, Crop Science Society of America, and Soil Science Society of America, Madison, WI.

Townsend, P.A., D.P. Helmers, C.C. Kingdon, B.E. McNeil, K.M. de Beurs, and K.N. Eshleman. 2009. Changes in the extent of surface mining and reclamation in the Central Appalachians detected using a 1976-2006 Landsat time series. Remote Sensing of Environment 113:62-72. https://doi.org/10.1016/j.rse.2008.08.012

Tucker, C.J. 1979. Red and photographic infrared linear combinations for monitoring vegetation. Remote Sensing of Environment 8(2):127-150. https://doi.org/10.1016/0034$\underline{4257(79) 90013-0}$

Walker B., A. Kinzig, and J. Langridge. 1999. Plant attribute diversity, resilience, and ecosystem function: the nature and significance of dominant and minor species. Ecosystems 2(2):95-113. https://doi.org/10.1007/s100219900062

Yang, Z., J. Li, C.E. Zipper, Y. Shen, H. Miao, and P.F. Donovan. 2018. Identification of the disturbance and trajectory types in mining areas using multitemporal remote sensing images. Science of the Total Environment 644:916-927. https://doi.org/10.1016/j.scitotenv.2018.06.341

Zipper, C.E., J.A. Burger, J.G. Skousen, P.N. Angel, C.D. Barton, V. Davis, and J.A. Franklin. 2011. Restoring forests and associated ecosystem services on Appalachian coal surface mines. Environmental Management 47(5):751-765. https://doi.org/10.1007/s00267-011-9670-z 